\title{
Micro, Small and Medium Enterprises in Goa: Growth Exploration
}

\author{
Sukhaji G. Naik
}

Abstract: According to Micro, Small and medium enterprises Act 2006, the MSME are classified into two categories viz, Manufacturing Enterprises which are engaged in the manufacturing of production of goods or employing plant and machinery in the process of value addition to the final product having a distinct name or character or use. Service Enterprises: The enterprises engaged in providing or rendering of services are defined in terms of investment in equipment. Now, MSMEs is defined on the basis of 'Annual Turnover' instead of investment in plant and machinery /Equipment. Incase of manufacturing sector, the enterprises whose annual turnover is less than Rs. 5 Crores are considered as 'Micro Enterprises' The enterprises whose annual turnover is between Rs. 5 crores to Rs. 75 crores are considered as 'Small Enterprises' and the enterprises whose annual turnover is between Rs. 75 crores to Rs. 250 crores are considered as Medium Enterprises.

A similar criteria are applied to define service sector enterprises as Micro, Small and Medium enterprises. At present approximately 36.1 million units of micro, small and medium enterprises are engaged in production in India. This sector provides employment to around 120 million people, These units represent around more than $45 \%$ of India's total export. The contribution of this sector to the country's Gross Domestic Product is about 8\%. A study carried out by the Confederation of Indian Industries (CII) on the Indian MSMEs reveals that the MSME's contribution to the India's GDP will be around $50 \%$ by 2024. Many units of MSME's are located in rural areas which are checking the migration from rural areas to urban areas.

Goa was liberated from the Portuguese regime yoke on 19th December 1961, and remained union territory along with Daman and Diu for several years; Goa was elevated to the status of 25th state in the Indian Union on 30th May 1987. It has a geographical area of $3702 \mathrm{Sq}$. Kms. and a population of 14.58 lakhs (2011 Census). The state is divided into two districts (North and South Goa) and Twelve talukas. This state has the highest per capita income in the country and the second lowest with respect to poverty ratio. Tourism, agriculture, industry, mining, construction, banking, trade and fishery are the main stay of the Goan economy. Goa with its unique natural beauty has emerged as one of the best and the most attractive tourist destinations in the world.

With a spread network of banking and financial institutions, the state is in the ideal position to attract investment. Goa today has over 8000 small scale industries employing over 60000 employees. The state has developed / established 20 industrial estates; some of them are among the best in the country. The industrial activities encompass about 50 sub sectors which include tourism, pharmaceuticals, electrical and automobile accessories etc. In spite of this, we are yet to achieve lot in the industrialization process. Goa has done fairly well in last two decades on the industrial front in spite of various handicaps. The explanation for this does not lie in any planned development strategy that the state

Revised Manuscript Received on July 22, 2019.

Dr. Sukhaji G. Naik, Associate Professor, Vice Principal and HOD, Dept. of Commerce, Vidya Prabodhini College of Commerce, Education, Computer and Management, Parvari Goa, India adopted-indeed there was a pointed lack of any such gearing up for accelerated industrial development and overall economic growth.

Keywords : MSME, Small Enterprises, CII, Service Enterprise.

\section{OBJECTIVES OF THE STUDY}

The broader objective of the study is to examine the growth trend of micro, small and medium enterprises with regard to the total number of units, total investment and employment provided to the people. Further, an attempt is also made to compare the growth of these units between North Goa district and South Goa district.

\section{HYPOTHESIS}

The following hypothesis are set for the study:

1) There is no significant difference in the growth of number of micro enterprises between North Goa and South Goa Districts.

2) There is no significant difference in the growth of number of small enterprises between North Goa and South Goa Districts.

3) There is no significant difference in the growth of number of medium enterprises between North Goa and South Goa Districts.

4) There is no significant difference between Investment of Micro enterprises North District and South District.

5) There is no significant difference between Investment of Small enterprises North District and South District.

6) There is no significant difference between Investment of Medium enterprises North District and South District.

7) There is no significant difference between Employment of Micro enterprises North District and South District.

8) There is no significant difference between Employment of small enterprises between North Goa and South Goa Districts.

9) There is no significant difference between Employment of Medium enterprises between North Goa and South Goa Districts. 


\section{DATA AND METHODOLOGY}

The study has purposively selected the Micro, Small and Medium Enterprises operating in the state of Goa. The study is based on secondary data and the necessary year wise data pertaining to the total number of micro, small, and medium enterprises, the total investment made in these enterprises and the total employment provided to the people for the period from 2007 - 08 to 2017-18 are collected from the Directorate of Industries and Mines, Govt. of Goa. Over and above , the necessary information is also collected from the reference books and periodicals. The collected data is analysed with the help of Index number (Chain Index) and Analysis of Variances (ANOVA) is employed to test the formulated hypothesis.

\section{ANALYSIS AND DISCUSSION}

Table- I: Growth Analysis of Micro, Small and Medium Enterprises in North Goa During 2007-8 To 2017-18 (Units)

(Figures in Actual)

\begin{tabular}{|c|c|c|c|c|c|c|c|c|}
\hline Year & Micro & Index & Small & Index & Medium & Index & Total & Index \\
\hline $2007-08$ & 34 & 100.00 & 12 & 100.00 & 10 & 100 & $\mathbf{2 5 6}$ & 100 \\
\hline $2008-09$ & 33 & 97.06 & 13 & 108.33 & 0 & 0 & $\mathbf{2 5 1 . 3 9}$ & 98.20 \\
\hline $2009-10$ & 41 & 124.24 & 21 & 161.54 & 0 & 0 & $\mathbf{3 4 7 . 7 8}$ & 138.34 \\
\hline $2010-11$ & 37 & 90.24 & 11 & 52.38 & 1 & 0 & $\mathbf{1 9 1 . 6 2}$ & 55.10 \\
\hline $2011-12$ & 32 & 86.49 & 25 & 227.27 & 0 & 0 & $\mathbf{3 7 0 . 7 6}$ & 193.48 \\
\hline $2012-13$ & 39 & 121.88 & 26 & 104.00 & 2 & 0 & $\mathbf{2 9 2 . 8 8}$ & 78.99 \\
\hline $2013-14$ & 65 & 166.67 & 27 & 103.85 & 5 & 250 & $\mathbf{3 6 7 . 5 1}$ & 125.48 \\
\hline $2014-15$ & 66 & 101.54 & 30 & 111.11 & 1 & 20 & $\mathbf{3 0 9 . 6 5}$ & 84.26 \\
\hline $2015-16$ & 333 & 504.55 & 178 & 593.33 & 11 & 1100 & $\mathbf{1 6 1 9 . 8 8}$ & 523.13 \\
\hline $2016-17$ & 576 & 172.97 & 362 & 203.37 & 13 & 118.18 & $\mathbf{1 3 2 7 . 3 4}$ & 81.94 \\
\hline $2017-18$ & 513 & 89.06 & 8 & 2.21 & 11 & 84.62 & $\mathbf{6 2 3 . 2 7}$ & 46.96 \\
\hline
\end{tabular}

Source: Statistics Department, Directorate of Industries, Trade and Commerce. Govt. of Goa

Note : Chain Index values are computed

Micro, small and medium enterprises occupy an important place in the economy in terms of supporting the growth and development of large scale industries as well as generating employment opportunities. The growth of micro, small and medium enterprises in North Goa district of Goa state is analyzed with the help of chain index and the number of Units as well as growth rate of these units for the period of 2007-08 to 2017-18 is displayed in the table 1 . It can be observed from the table that the year wise growth analysis of micro enterprises reveals a fluctuating trend and there is no consistent growth in the number of units. During 2015-16, the year wise growth analysis recorded $504.55 \%$ which happens to be the highest. It was further observed that during 2015-16 to $2017-18$, the micro units have made an impressive growth and the number of units considering increased from year to year.
The year wise growth analysis of small enterprises during 2007-08 to 2017-18, shows that except during 2015-16 and 2016-17, the growth is observed to be more or less the same with a marginal variation. Whereas during 2015-16 and 16-17, the small enterprises have registered a remarkable growth viz, 178 units and 362 units respectively. In 2017-18, small units have registered a negligible growth. Incase of medium enterprises, the performance is very poor as in many years, no medium enterprises were set up and during other years, only few units were registered. The overall growth of micro, small, and medium enterprises also have recorded fluctuating trend. This clearly indicates that there is no balanced growth of business enterprises in the North Goa district. 
Table- II: Growth Analysis of Micro, Small and Medium Enterprises in South Goa During 2007-8 To 2017-18 (Units)

\begin{tabular}{|c|c|c|c|c|c|c|c|c|}
\hline Year & Micro & Index & Small & Index & Medium & Index & Total & Index \\
\hline $2007-08$ & 6 & 100.00 & 2 & 100.00 & 0 & 0 & $\mathbf{2 0 8}$ & 100.00 \\
\hline $2008-09$ & 18 & 300.00 & 9 & 450.00 & 0 & 0 & $\mathbf{7 7 7}$ & 373.56 \\
\hline $2009-10$ & 32 & 177.78 & 12 & 133.33 & 2 & 0 & $\mathbf{3 5 7 . 1 1}$ & 45.96 \\
\hline $2010-11$ & 25 & 78.13 & 14 & 116.67 & 0 & 0 & $\mathbf{2 3 3 . 7 9}$ & 65.47 \\
\hline $2011-12$ & 27 & 108.00 & 11 & 78.57 & 0 & 0 & $\mathbf{2 2 4 . 5 7}$ & 96.06 \\
\hline $2012-13$ & 19 & 70.37 & 16 & 145.45 & 0 & 0 & $\mathbf{2 5 0 . 8 2}$ & 111.69 \\
\hline $2013-14$ & 48 & 252.63 & 18 & 112.50 & 3 & 0 & $\mathbf{4 3 4 . 1 3}$ & 173.08 \\
\hline $2014-15$ & 33 & 68.75 & 26 & 144.44 & 4 & 133.33 & $\mathbf{2 7 6 . 1 9}$ & 63.62 \\
\hline $2015-16$ & 165 & 500.00 & 102 & 392.31 & 17 & 425.00 & $\mathbf{1 1 7 6 . 3 1}$ & 425.90 \\
\hline $2016-17$ & 228 & 138.18 & 144 & 141.18 & 4 & 23.53 & $\mathbf{6 5 5 . 3 6}$ & 55.71 \\
\hline $2017-18$ & 1319 & 578.51 & 152 & 105.56 & 8 & 200.00 & $\mathbf{2 1 6 3 . 0 6}$ & 330.06 \\
\hline
\end{tabular}

Source: Statistics Department, Directorate of Industries, Trade and Commerce. Govt. of Goa

Note : Chain Index values are computed

The growth of micro, small and medium enterprises in South Goa district of Goa state is analyzed with the help of chain index and the number of Units as well as growth rate of these units for the period of 2007-08 to 2017-18 is displayed in the table 2 . It can be observed from the table that the year wise growth analysis of micro enterprises reveals a fluctuating trend and there is no consistent growth in the number of units. During 2017-18, the year wise growth analysis recorded $578.51 \%$ which happens to be the highest. It was further observed that during 2015-16 to 2017-18, the micro units have made an impressive growth and the number of units considering increased from year to year.

The year wise growth analysis of small enterprises during 2007-08 to 2017-18, shows that except during 2015-16 and 2016-17, the growth is observed to be more or less the same with a marginal variation. Whereas during 2016-17 and 2017-18, the small enterprises have registered a remarkable growth viz, 144 units and 152 units respectively. Incase of medium enterprises the performance year 2015-16 has shown the highest growth viz. 17 Units. The overall growth of micro, small, and medium enterprises also have recorded fluctuating trend. This clearly indicates that there is no balanced growth of business enterprises in the South Goa district.

Table- III: Growth Analysis of Micro, Small and Medium Enterprises in North Goa During 2007-8 To 2017-18 (Employment)

\begin{tabular}{|c|c|c|c|c|c|c|c|c|}
\hline Year & Micro & Index & Small & Index & Medium & Index & Total & Index \\
\hline $2007-08$ & 242 & 100.00 & 508 & 100.00 & 0 & 0 & $\mathbf{9 5 0}$ & 100.00 \\
\hline $2008-09$ & 284 & 117.36 & 422 & 83.07 & 78 & 0 & $\mathbf{9 8 4 . 4}$ & 103.62 \\
\hline $2009-10$ & 394 & 138.73 & 1308 & 309.95 & 59 & 75.64 & $\mathbf{2 2 1 0}$ & 224.46 \\
\hline $2010-11$ & 258 & 65.48 & 670 & 51.22 & 39 & 66.10 & $\mathbf{1 0 8 4}$ & 49.04 \\
\hline $2011-12$ & 264 & 102.33 & 1237 & 184.63 & 0 & 0 & $\mathbf{1 7 8 8}$ & 164.99 \\
\hline $2012-13$ & 239 & 90.53 & 1595 & 128.94 & 240 & 0 & $\mathbf{2 2 9 3}$ & 128.27 \\
\hline $2013-14$ & 901 & 376.99 & 1493 & 93.61 & 337 & 140.42 & $\mathbf{3 2 0 2}$ & 139.60 \\
\hline $2014-15$ & 600 & 66.59 & 1811 & 121.30 & 102 & 30.27 & $\mathbf{2 7 0 1}$ & 84.36 \\
\hline $2015-16$ & 1964 & 327.33 & 5815 & 321.09 & 816 & 800.00 & $\mathbf{9 2 4 3}$ & 342.24 \\
\hline $2016-17$ & 3485 & 177.44 & 5264 & 90.52 & 1639 & 200.86 & $\mathbf{1 0 6 5 6}$ & 115.28 \\
\hline $2017-18$ & 3062 & 87.86 & 4204 & 79.86 & 800 & 48.81 & $\mathbf{8 2 3 4}$ & 77.27 \\
\hline
\end{tabular}

Source: Statistics Department, Directorate of Industries, Trade and Commerce. Govt. of Goa Note : Chain Index values are computed

Micro, Small and medium enterprises play vital role in providing employment opportunities to unskilled and semi-skilled manpower. The total number of manpower employed by MSM's operating in the North Goa district is depicted in table 3 . It can be viewed from the table that the yearwise growth of manpower shows that during 2015-16, 16-17 and 2017-18, the micro enterprises have recorded the highest manpower employed and the computed chain index values convey that there is no stable employment and a 
variation is observed across all the years. This speaks a seasonable employment for some workers. this variation in the employment could be because of seasonal demand for the products produced by the MSMS . Incase of small enterprises, a similar observation is made as far as the employment is concerned. During 2015-16, 16-17 and 17-18, the small enterprises have shown good performance in creating employment opportunities . The medium enterprises have also exhibited a similar growth as recorded by the micro and small business enterprises. The overall analysis of employment generated by MSM's also indicates a fluctuation trends over the years. This overall variation in the employment might be because of poor linkeage with apex bodies and large scale industries.

Table- IV: Growth Analysis of Micro, Small and Medium Enterprises in South Goa During 2007-8 To 2017-18 (Employment)

\begin{tabular}{|c|c|c|c|c|c|c|c|c|}
\hline Year & Micro & Index & Small & Index & Medium & Index & Total & Index \\
\hline $2007-08$ & 27 & 100.00 & 86 & 100.00 & 0 & 0 & 313 & 100.00 \\
\hline $2008-09$ & 164 & 607.41 & 285 & 331.40 & 0 & 0 & $\mathbf{1 3 8 8}$ & 443.39 \\
\hline $2009-10$ & 163 & 99.39 & 241 & 84.56 & 69 & 0 & $\mathbf{6 5 7}$ & 47.34 \\
\hline $2010-11$ & 179 & 109.82 & 475 & 197.10 & 0 & 0 & $\mathbf{9 6 0 . 9}$ & 146.27 \\
\hline $2011-12$ & 192 & 107.26 & 424 & 89.26 & 0 & 0 & $\mathbf{8 1 2 . 5}$ & 84.56 \\
\hline $2012-13$ & 140 & 72.92 & 479 & 112.97 & 0 & 0 & $\mathbf{8 0 4 . 9}$ & 99.06 \\
\hline $2013-14$ & 281 & 200.71 & 583 & 121.71 & 347 & 0 & $\mathbf{1 5 3 3}$ & 190.51 \\
\hline $2014-15$ & 262 & 93.24 & 601 & 103.09 & 239 & 68.88 & $\mathbf{1 2 9 8}$ & 84.67 \\
\hline $2015-16$ & 1089 & 415.65 & 3232 & 537.77 & 1945 & 813.81 & $\mathbf{7 2 1 9}$ & 556.06 \\
\hline $2016-17$ & 2283 & 209.64 & 4685 & 144.96 & 239 & 12.29 & $\mathbf{7 5 6 2}$ & 104.74 \\
\hline $2017-18$ & 2128 & 93.21 & 2826 & 60.32 & 394 & 164.85 & $\mathbf{5 5 0 2}$ & 72.76 \\
\hline
\end{tabular}

Source: Statistics Department, Directorate of Industries, Trade and Commerce. Govt. of Goa

Note : Chain Index values are computed

The total number of manpower employed by MSM's operating in the South Goa district is depicted in table 4. It can be viewed from the table 4 that manpower employment was highest in the year 2016-17 and 2017-18 in micro enterprises. Similarly, Small enterprises it has recorded very high growth rate in the year 2016-17. In case of Medium enterprises, it shows that manpower employment growth is high in the year 2015-16. The overall analysis of employment generated by MSM's also indicates a fluctuation trends over the years. Due to fluctuations in demand there is overall variations in employment.

Table-V: Growth Analysis of Micro, Small and Medium Enterprises in North Goa During 2007-8 To 2017-18 (Investment) (Rs. In Lakhs)

\begin{tabular}{c|c|c|c|c|c|c|c|c|}
\hline Year & Micro & Index & Small & Index & Medium & Index & Total & index \\
\hline $2007-08$ & 474 & 100.00 & 1573 & 100.00 & 0 & 0 & $\mathbf{2 2 4 7}$ & 100.00 \\
\hline $2008-09$ & 440.65 & 92.96 & 2130 & 135.41 & 1583 & 0 & $\mathbf{4 3 8 2}$ & 195.017 \\
\hline $2009-10$ & 782.21 & 177.51 & 4859.7 & 228.15 & 946.83 & 59.81 & $\mathbf{6 9 9 4}$ & 159.616 \\
\hline $2010-11$ & 665.06 & 85.02 & 2440.1 & 50.21 & 1157 & 122.20 & $\mathbf{4 3 9 7}$ & 62.870 \\
\hline $2011-12$ & 778.97 & 117.13 & 7514.54 & 307.96 & 0 & 0 & $\mathbf{8 7 1 9}$ & 198.267 \\
\hline $2012-13$ & 868.98 & 111.56 & 10107.59 & 134.51 & 2144.56 & 0 & $\mathbf{1 3 3 6 7}$ & 153.318 \\
\hline $2013-14$ & 2213.71 & 254.75 & 7779.97 & 76.97 & 3421.09 & 159.52 & $\mathbf{1 3 7 4 6}$ & 102.838 \\
\hline $2014-15$ & 1485.98 & 67.13 & 8397.06 & 107.93 & 746 & 21.81 & $\mathbf{1 0 8 0 4}$ & 78.595 \\
\hline $2015-16$ & 2541.99 & 171.06 & 17991.27 & 214.26 & 7717 & 1034.45 & $\mathbf{2 8 6 3 6}$ & 265.044 \\
\hline $2016-17$ & 3062 & 120.46 & 19186 & 106.64 & 10496 & 136.01 & $\mathbf{3 2 9 7 1}$ & 115.140 \\
\hline $2017-18$ & 3103 & 101.34 & 15774 & 82.22 & 7388 & 70.39 & $\mathbf{2 6 4 4 9}$ & 80.217 \\
\hline
\end{tabular}

Source: Statistics Department, Directorate of Industries, Trade and Commerce. Govt. of Goa Note : Chain Index values are computed

The size of capital investment in manufacturing of goods and providing services assumes greater importance in promoting economic activities and ancillary economic sectors. The year wise total investment made in micro, small and medium business enterprises and the computed values of chain index of North Goa district are pretended in Table 5. It can be witnessed from the table that in case of micro enterprises the total Rs. 474 Lakh was made during 2007-08 and during the last year, the total investment stood at Rs. 3103 
Lakhs. The computed index values show that during study period, the year wise investment was observed to be an upward trend with a marginal variation. This much investment in micro enterprises indicates expansion of manufacturing operations during the study period. Incase of small enterprises, the total investment made was Rs. 1573 Lakhs and in the year 2012-13 and 2015-16, the small enterprises have made a record of highest investment during the stay period. The year wise index values show that there is an increasing trend in the investment with certain percentage of variations was could be due to economic slowdown and fluctuation in the demand for goods and services. The total investment in medium enterprises, it is observed that in the year 2016-17, the medium enterprises have registered the highest investment of Rs. 10496 lakhs followed by Rs. 7717 lakhs as the second highest investment. The year 2017-18 and 2011-12, the investment made is observed to zero. The year wise investment also shows a fluctuating trend during the stay period.

Table-VI: Growth Analysis of Micro, Small and Medium Enterprises in South Goa During 2007-8 To 2017-18 (Investment)

(Rs. In Lakhs)

\begin{tabular}{|c|c|c|c|c|c|c|c|c|}
\hline Year & Micro & index & Small & Index & Medium & index & Total & Index \\
\hline $2007-08$ & 34.28 & 100.00 & 834.55 & 100.00 & 0 & 0 & $\mathbf{1 0 6 9}$ & 100.00 \\
\hline $2008-09$ & 324.86 & 947.67 & 1882.22 & 225.54 & 0 & 0 & $\mathbf{3 3 8 0}$ & 316.26 \\
\hline $2009-10$ & 1033.14 & 318.03 & 2255.33 & 119.82 & 1538.42 & 0 & $\mathbf{5 2 6 5}$ & 155.75 \\
\hline $2010-11$ & 626.89 & 60.68 & 4061.56 & 180.09 & 0 & 0 & $\mathbf{4 9 2 9}$ & 93.63 \\
\hline $2011-12$ & 583.73 & 93.12 & 2491.35 & 61.34 & 0 & 0 & $\mathbf{3 2 3 0}$ & 65.52 \\
\hline $2012-13$ & 439.27 & 75.25 & 6459.58 & 259.28 & 0 & 0 & $\mathbf{7 2 3 3}$ & 223.98 \\
\hline $2013-14$ & 1069.33 & 243.43 & 4284.71 & 66.33 & 5558.36 & 0 & $\mathbf{1 1 2 2 2}$ & 155.14 \\
\hline $2014-15$ & 903.63 & 84.50 & 3871.9 & 90.37 & 4795.6 & 86.28 & $\mathbf{9 7 4 6}$ & 86.85 \\
\hline $2015-16$ & 1292 & 142.98 & 11964 & 309.00 & 11199 & 233.53 & $\mathbf{2 4 9 0 7}$ & 255.56 \\
\hline $2016-17$ & 1354 & 104.80 & 13084 & 109.36 & 2848 & 25.43 & $\mathbf{1 7 5 0 0}$ & 70.26 \\
\hline $2017-18$ & 2044 & 150.96 & 11965 & 91.45 & 6044 & 212.22 & $\mathbf{2 0 2 9 5}$ & 115.97 \\
\hline
\end{tabular}

Source: Statistics Department, Directorate of Industries, Trade and Commerce. Govt. of Goa

Note : Chain Index values are computed

The year wise total investment made in micro, small and medium business enterprises and the computed values of chain index of South Goa district are pretended in Table 6. It can be witnessed from the table that in case of micro enterprises the total Rs. 34.28 Lakh was made during 2007-08 and during the last year, the total investment stood at Rs. 2044 Lakhs. The computed index values show that during study period, the year wise investment was observed to be an upward trend with a marginal variation. This much investment in micro enterprises indicates expansion of manufacturing operations during the study period. Incase of small enterprises, the total investment made was Rs. 834.55 Lakhs during the year 2007-08 and 2012-13, the small enterprises have made a record of highest investment during the study period. The year wise index values show that there is an increasing trend in the investment with certain percentage of variations which could be due to fluctuation in demand. The total investment in medium enterprises, it is observed that in the year 2013-14, the medium enterprises have registered the highest investment of Rs. 5558.36 lakhs followed by Rs. 4795.6 lakhs as the second highest investment.

\section{TESTING OF HYPOTHESIS}

Table-VII:Testing of Hypothesis

\begin{tabular}{|c|l|c|c|}
\hline Sr. No. & \multicolumn{1}{|c|}{ Null Hypothesis } & P-Value & $\begin{array}{c}\text { Accepted/ } \\
\text { Rejected }\end{array}$ \\
\hline 1. & $\begin{array}{l}\text { There is no significant difference in the growth of } \\
\text { uumber of micro enterprises between North Goa } \\
\text { and South Gou Districts. }\end{array}$ & 0.818 & Rejected \\
\hline 2. & $\begin{array}{l}\text { There is no significant difference in the growth of } \\
\text { number of small enterprises between North Goa and } \\
\text { South Goa Districts. }\end{array}$ & 0.495 & Rejected \\
\hline 3. & $\begin{array}{l}\text { There is no significant difference in the growth of } \\
\text { number of medium enterprises between North Goa } \\
\text { and South Gou Districts. }\end{array}$ & 0.456 & Rejected \\
\hline 4. & $\begin{array}{l}\text { There is no significant difference between } \\
\text { Investment of Micro enterprises North District and }\end{array}$ & 0.10 & Rejected \\
\hline 5. & $\begin{array}{l}\text { South District. } \\
\text { There is no significant difference between } \\
\text { Investment of Small enterprises North District and } \\
\text { South District. }\end{array}$ & 0.149 & Rejected \\
\hline 6. & $\begin{array}{l}\text { There is no significant difference between } \\
\text { Investment of Medium enterprises North District } \\
\text { and South District. }\end{array}$ & 0.73 & Rejected \\
\hline 7. & $\begin{array}{l}\text { There is no significant difference between } \\
\text { Employment of Micro enterprises North District } \\
\text { and South District. }\end{array}$ & 0.48 & Rejected \\
\hline 8. & $\begin{array}{l}\text { There is no significant difference between } \\
\text { Employment of small enterprises berween North } \\
\text { Goa and South Goa Districts. }\end{array}$ & 0.312 & Rejected \\
\hline 9. & $\begin{array}{l}\text { There is no significant difference between } \\
\text { Employment of Medium enterprises between North } \\
\text { Goa and South Goa Districts. }\end{array}$ & 0.66 & Rejected \\
\hline
\end{tabular}


The results of the hypothesis tested with the help of ANOVA are displayed in table 7. The calculated P-Values of all the null hypothesis are more than 0.05 and therefore, all the null hypothesis are rejected and alternative hypothesis are accepted. It means, there is a significant difference in the growth of micro, small and medium enterprises, with regard to number of units, employment and investment between North and South Goa Districts.

\section{CONCLUSION}

The study has introspected the growth of Micro, Small and Medium Enterprises in terms of the total number of Units, total investment and the total employment for the period from 2007-08 to 2017-18. The analysis and discussion reveals that on the whole, all the Units viz. micro, small and medium have registered a fluctuating growth trend during the study period with regard to the total number of units, total investment and employment. The year wise computed values of chain index showed a considerable variation in the year wise growth. The formulated hypothesis are tested and the results show that all the formulated null hypothesis are rejected and alternate hypothesis are accepted. It means a significant difference exists in the growth of micro, small and medium enterprises with regard to number of units, investment and employment between North Goa district and South Goa district.

\section{REFERENCES}

1. Statistics Department, Directorate of Industries, Trade and Commerce. Govt. of Goa. Year wise data from 2007-08 to 2017-18

2. Economic survey Report 2016-17

3. Economic survey Report 2017-18

4. Hopkins, Eric. Industrialisation and Society : A Social History, 1830-1951, Routledge, 2000. ProQuest Ebook Central, https://ebookcentral.proquest.com/lib/inflibnet-ebooks/detail.action? docID $=165823$.

5. Gupta, B. N. Business Statistics and elementary, SBPD Publications, 2018

6. Khanka, S S. Entrepreneurial development, S. Chand and company Pvt. Ltd, 2012

7. The Gazette of India, Part II section 1, Published by Authority, New Delhi, Friday June 16, 2006.

8. http://karnatakaindustry.gov.in/kn/images/program-schemes/acts-rul es-policies/ACT-MSMED\%20ACT\%202006-FAQ.pdf 